\title{
モモの成熟後期の龫化にかかわるエチレン生成の引き金はオーキシンである 硬肉モモを用いた解析から
}

わが国で一般に栽培されているモモ（普通モモ）は， 収穫後に果肉が急激に軟化するため, 日持ち性は極めて 低く，押し傷などもつきやすいことから流通過程で廃棄 される果実も多い，普通モモは成熟期が近くなると，呼 吸の上昇, クロロフィルの分解による地色の抜け, 果肉 硬度の低下，着色，香気成分の増加などが起こる，これ らのモモの成熟には，ガス状の植物ホルモンであるエチ レンが深く関与している。生体内において，エチレンは メチオニンから, S-アデノシルメチオニン (SAM), 1アミノシクロプロパンカルボン酸 (ACC) を経て合成 される。この経路において SAMからACCの生合成を 触媒する ACC 合成酵素（ACC synthase; ACS）が律速 酵素と考えられている。普通モモは成熟期になると， $\mathrm{ACS}$ アソジーンの一つ, PpACS1の発現量が増加す ることでエチレン生成量も増加する(1).このエチレンの 作用により，ポリガラクチュロナーゼ（PG）をはじめ とする細胞壁修飾酵素などの遺伝子の発現量が増加し, 軟化・成熟が進行すると考えられている。しかし，成熟 期におけるエチレン生成の引き金，すなわちP P A C S I の発現を誘導する因子については不明であった。

モモには硬肉と呼ばれる夕イプがあり, 普通モモ品種間 の交雑で得られた実生の中から発見された(2).わが国では 「おどろき」,「まなみ」などの品種が少量ながら生産され ている，硬肉モモは，成熟に伴う果皮色の変化，糖度の上 昇, 減酸などは普通モモと同様に進行するにもかかわらず, 果肉は収穫後もほとんど軟化しない。過去の交雑試験か ら硬肉を決めるのは劣性の 1 遺伝子座 $(h d)$ であると考え られている. 成熟期の硬肉モモではPpACS1の発現量の 増加が起こらないためにエチレン生成が起こらず, 軟化し ないことが明らかにされた(1).一般的にエチレンは葉な どに傷を与えたときにも生成されるが，硬肉モモであっ ても，傷害を与えた葉や果実においてはPpACS1 が誘導 され，エチレンも生成される。したがって，硬肉モモの 成熟果実におけるエチレン生成の抑制は，PpACS1 遺伝 子の欠損によるものではなく，果実成熟に伴う発現が特 異的に抑制されており，それには植物ホルモンの一つで あるオーキシンが関与していることが明らかとなった (3).

植物におけるオーキシンの作用は極めて多様であり, 発
生，発芽から生長，花芽形成などの生理現象における内 在性の情報因子として働くだけでなく，光，重力といった 環境刺激に対する応答因子としても重要な役割を果たす ことがよく知られている，その作用の中に果実成熟に関与 している可能性を示す知見も得られていた，モモでは，果 実成熟期に打けるエチレン生成量の増加が内生の天然 オーキシンであるインドール酢酸（IAA）の増加と一致す ること(4)，モモ果肉デイスクにオーキシン処理をするとエ チレン生成が起こること(5)などの知見が報告されている.

普通モモおよび硬肉モモ果実生育期間に招ける内生 IAA量はいずれのモモにおいても細胞分裂や細胞肥大 が著しい幼果期に最も多く，その後果実の生育に伴い 徐々に減少し, 収穫適期の 2 週間ほど前には検出限界值 以下となる。そのような状態が数日続いた後，普通モモ ではIAA 量は収穫適期に向けて急激に増加する。一方, 硬肉モモでは，普通モモとは異なり収穫期に達しても IAA 量の急激な増加は認められない（図1)。硬肉モモ 果実に合成オーキシン剤を処理するとPpACSIが誘導 されエチレン生成が起こり軟化する。一方，普通モモ果 実にオーキシン作用阻害剂処理をすると，PpACS1 の発 現量は低く，エチレン生成量は少なく，果肉硬度は高い 傾向を示す。このように，普通モモでは成熟後期に多量 に合成されたIAAによってPpACSI の発現量が増加し, エチレンが多量に生成される。硬肉モモでは，成熟後期 に達してもIAA量が増加しないためにエチレン生成が 誘導されず，軟化が起こらないものと考えられる．すな わち成熟に伴うエチレン生成㧍よび軟化は内生オーキシ ンによって制御されていると考えられる（図1）.

モモ果実は生育の後期に入ると急激に肥大するととも に，緩やかに軟化する．このような傾向は収穫後に急激な 軟化が見られない硬肉モモでも同様であり，収穫期には 果肉硬度が $3 \sim 4 \mathrm{~kg}$ まで低下する。 この時期は普通モモで あってもエチレン生成量, IAA 量ともに極めて低いことか ら，このような緩やかな軟化は，収穫後の急激な軟化とは 異なり，エチレンもオーキシンも関与しないものと思われ る. 細胞壁を分解・修飾する酵素の遺伝子を対象とした モモ果実の成熟期における網羅的な発現解析により，一部 の遺伝子はエチレン生成量が増加する前から発現し，かつ 


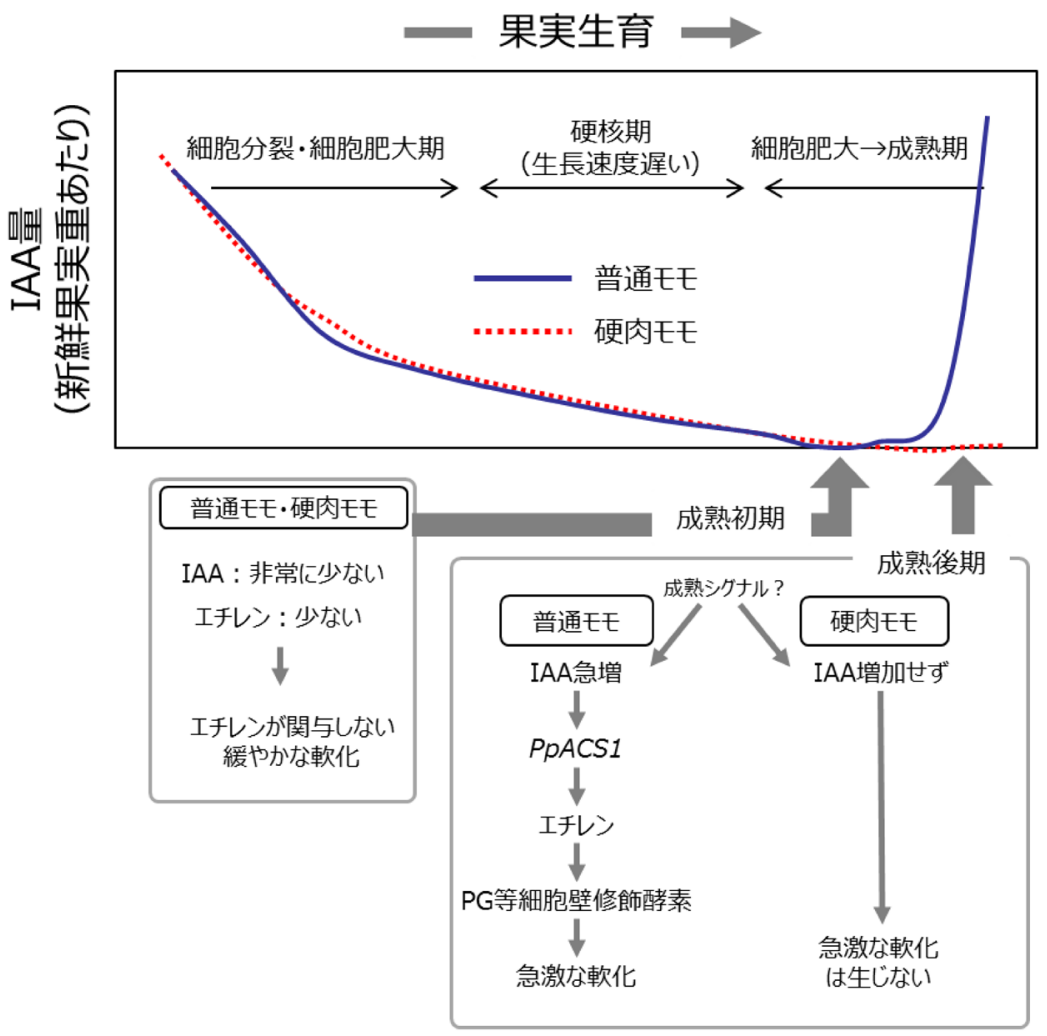

図 1・モモ果実生育期における IAA 量の変化の イメージ図（上）と成熟期における植物ホルモ ンの影響についての模式図（下）

転写はエチレンによって促進されることはなく, むしろ抑 制されることが明らかにされている(6)，以上のように，モ モの軟化は2段階で制御されていると考えられる（図1).

果実の生育および成熟期における植物ホルモン同士の クロストークについては，トマトをはじめとするさまざ まな植物において研究されており, 成熟期ではエチレ ン，オーキシン，アブシジン酸 $(\mathrm{ABA})$ のかかわりが 指摘されている ${ }^{(7)}$. 果実成熟期のオーキシンによるエチ レン生成の誘導はモモに限らず，ほかのクライマクテ リック型果実においても同様に起きている可能性は高い (立木，未発表)。エチレンは成熟の現場を司る植物ホル モンとしてよく知られているが，その制御にオーキシン が関与していることが明らかとなり，今後，成熟後期の オーキシン生成を促すシグナル物質の存在などが明らか にされることを期待したい.

1) M. Tatsuki, T. Haji \& M. Yamaguchi: J. Exp. Bot., 57, 1281 (2006).

2) M. Yoshida: Bull. Fruit Tree Res. Sta., 3, 1 (1976).

3) M. Tatsuki, N. Nakajima, H. Fujii, T. Shimada, M. Nakano, K. Hayashi, H. Hayama, H. Yoshioka \& Y. Nakamura: J. Exp. Bot., 64, 1049 (2013).

4) P. Tonutti, P. Casson \& A. Ramina: J. Am. Soc. Hortic. Sci., 116, 274 (1991).
5) A. Ohmiya: Sci. Hortic. (Amsterdam), 84, 309 (2000).

6) L. Trainotti, D. Zanin \& G. Casadoro: J. Exp. Bot., 54, 1821 (2003).

7) R. Kumar, A. Khurana \& A. K. Sharma: J. Exp. Bot., 65, 4561 (2014)

(立木美保，農業・食品産業技術総合研究機構果樹茶業研 究部門)

プロフィール

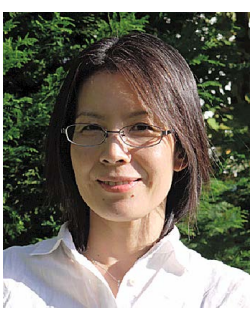

立木 美保（Miho TATSUKI）

<略歴 $>1997$ 年名古屋大学大学院生命農 学研究科博士課程前期課程修了 $/ 2000$ 年 同博士課程後期課程単位取得退学/同年 (財)科学技術交流財団任期付研究員 $/ 2001$ 年(株) 本田技術研究所和光基礎技術研究七 ンター契約研究員/同年学位取得, 博士 (農学) / 同年 10 月農研機構果樹研究所任 期付研究員 $/ 2006$ 年同主任研究員 $/ 2016$ 年農研機構果樹茶業研究部門上級研究員, 現在に至る<研究テーマと抱負 > 果実の成 熟生理, 鮮度保持機構の解明. 最近は果実 の見た目だけではなく美味しさを保つ貯蔵 方法とその分子メカニズムに注目している <趣味>園芸, スポーツ, 読書 DOI: 10.1271/kagakutoseibutsu.54.457 